\title{
A Comparison of Incumbency Across Institutions: A Look at the House, Senate, and Governorships
}

\section{Brad Lockerbie}

Using the American National Election Studies of 1990, 1994, and 1998, we can see that there is an incumbency advantage for governors, senators, and members of the House of Representatives. There is, however, some variability to the magnitude of the incumbency advantage. Moreover, it appears to follow a rather sensible pattern. It appears to be strongest for members of the House and weakest for Governors. When looking at House elections, we can see that incumbency is more powerful than is party identification. When we look at senatorial and gubernatorial elections, the items appear to be more evenly matched. When we look at evaluations of the national parties performance and expectations of performance, the picture becomes much more muddy. Gubernatorial candidates consistently avoid being held accountable for their national parties past economic performance. Candidates for the House and Senate are largely able to avoid responsibility for the past economic performance of their national parties. Economic expectations, however, are modestly more related to vote choice.

Most studies of voting behavior simply look at one electoral level and leave it at that. We either look at voting behavior in presidential elections and stop or we look at House elections and stop. There are, of course, exceptions, but the focus on one level does appear to dominate the literature. Moreover, when we see multiple offices considered, we infrequently see the development of a theory of what we should expect to see at the various levels. In those manuscripts, we either see a comparison of voting behavior in presidential and House elections or a comparison of voting behavior in House and Senate elections. Here, I take a different approach. I examine voting behavior across three levels: House, Senate, and gubernatorial. Senate and House elections are often studied, but gubernatorial elections are a relative oddity in the literature.

Although some have devoted attention to gubernatorial elections (Bibby 1983; Holbrook-Provo 1987; Kenny 1983; Patterson 1982; Pierson 1977; Tompkins 1984 and 1988; and Turett 1971), Squire (1992, 125) points out, "scholars of American government all but ignore the office and its holders in favor of national politics." Jewell (1982) rightly points out that state politics is in general an understudied arena of politics. Moreover, he asserts we need to ascertain whether voting behavior is the same at the state level as it is at the national level. Similarly, Chubb (1988) argues that greater attention needs to be paid to state elections, especially since governors have

BRAD LOCKERBIE is an associate professor of political science at the University of Georgia.

The American Review of Politics, Vol. 25, Winter, 2004: 287-303

(C)2004 The American Review of Politics 
more resources today, such as higher salaries, improvements in staff, and greater constitutional authority. Unfortunately, most studies of gubernatorial elections either focus only at the aggregate level or fail to make explicit comparisons across levels of elections. This study will also focus on voting behavior at the individual level. Here, the work will employ identical statistical models of voting behavior. By looking at elections in this manner, we will have a better idea of the dynamics of individual vote choices across levels. This will, I hope, prove a useful complement to the aggregate studies that have already been completed. Using the American National Election Studies, this work will make such comparisons across gubernatorial, Senate, and House elections for the years 1990, 1994, and 1998.

Incumbency is a well known influence on voting behavior in House elections (Erikson 1972; Erikson and Wright 1989; Fiorina 1981a; Johannes and McAdams 1981; and Lockerbie 1999), and attempts to explain this phenomenon have been quite extensive. Tufte argues that the source of the incumbency advantage is redistricting. Fiorina (1977, as well as others [e.g., Cain, Ferejohn, and Fiorina 1987; Ferejohn 1977; Yiannakis 1981]), argues that the source of the incumbency advantage is the growing role of constituency service and pork barrel projects. All of these explanations have been subjected to considerable debate within the political science. What is not subject to much debate is the presence of an incumbency advantage for House incumbents. As Charles O. Jones $(1981,458)$ stated so pointedly, "one more article demonstrating that House incumbents tend to win reelection will induce a spontaneous primal scream among all congressional scholars across the nation." The impetus behind this manuscript is not to show that empirical regularity yet again, but rather to offer a comparison to other levels of elections.

Looking at Senate elections, we see much the same picture. Incumbent senators are very likely to get reelected. Individual constituents are more likely to vote for incumbents than challengers. The difference is one of magnitude. Typically, incumbent senators are not as safe as incumbent members of the House. Instead of being reelected $95-98 \%$ of the time, incumbent Senators languish with a reelection rate in the mid-70's to mid-80's (Ornstein, Mann, and Malbin 1987). We should not be terribly surprised by the modest drop in success. Unlike members of the House, incumbent Senators often draw well-financed quality challengers (Abramowitz 1988). Similarly, members of the Senate have less control over the media coverage of their performance in office than do House members (Jacobson 2001). Nonetheless, incumbent Senators are incumbents. They, presumably, have some political acumen. They were able to win at least one election to office, and it would be surprising if they did not have the wherewithal to take advantage of some of the perquisites of office when seeking another term. ${ }^{2}$ 
Should we expect an incumbency advantage for governors? At the most basic level, we should note that incumbent governors seeking reelection are by definition successful politicians; they have won statewide office at least once before. Jewell and Olson (1988) point out that being an incumbent governor has both advantages and disadvantages. On the plus side, incumbent governors are likely to be better known than their opponents, voters may believe experience is an asset, and they might be in a better position than either their challengers or open seat candidates to command political resources, such as campaign funding and the state party organization. On the negative side, incumbent governors might be held responsible for increased taxes, scandals that develop during their administration, and programs disliked by the voters. Incumbent governors bear more individual responsibility for the operation of the state government than do individual members of Congress (either House members or senators) for the actions taken by the national government. Finally, incumbent governors might bear responsibility for the state economy, while members of Congress might be able to place responsibility for the national economy on the shoulders of other political actors.

While there are arguments concerning whether we should expect an incumbent governor to be advantaged electorally, we should note most studies of gubernatorial elections find that there is an advantage to being an incumbent (Cowart 1973; Kingston 1989; Patterson 1982; Pierson 1977; Seroka 1980; etc.). Chubb (1988), however, finds that incumbency is not terribly advantageous for governors. Consequently, while we should probably expect there to be an advantage for incumbent governors, we are by no means certain one exists. Moreover, if there is only a weak advantage, we should not be startled. Testing this hypothesis at the individual level should shed some light on this proposition.

If we examine the relationship between incumbency and individual voting behavior, the foregoing leads us to the following expectations. Incumbent members of the House should have the easiest time garnering the votes of their constituents. Incumbent members of the House can claim credit for all the good that happens within the district and they can avoid blame for problems associated with the national government. With their greater control over media exposure and their greater levels of contact with individual constituents, they should have the safest elective job of the three. When we turn to the comparison of Senators and governors, the picture is not quite as clear. Both incumbent governors and Senators have advantages and disadvantages when seeking reelection. While they are, for the most part, reasonably astute politicians and they have a greater ability to control the flow of resources of campaign resources than do their challengers, they also have a greater likelihood of drawing quality challengers than do House members. Statewide 
candidates, in most cases, can make more efficient use of campaign resources. Statewide races make the use of television more reasonable for Senate and gubernatorial candidates. Moreover, the news media are more interested in statewide races than in House races. ${ }^{3}$ In short, it is hard to distinguish between the two. Nonetheless, governors, being the executive, are more likely to be held responsible for failures than are Senators, who can still shift blame onto others more easily. Consequently, we should expect Senators to be better able than governors to make use of the power of incumbency when seeking reelection. To close, incumbent members of the House ought to be most able to take advantage of the power of incumbency when seeking reelection; second, incumbent Senators; and last incumbent governors.

Before proceeding, we should look at the bivariate relationship between incumbency and vote choice across these three levels of office for these years. Table 1 shows the bivariate logistic regression equations. Here, we can see quite clearly that incumbency is statistically significant regardless of the electoral office we are examining. We should note that the explanatory power follows the pattern many would expect. Incumbency does the best job of explaining the variation when it comes to House elections, next Senate elections, and then finally gubernatorial elections. Table 2, however, shows the probability of voting Republican under the three different values for the incumbency variable (Democratic incumbent, open seat, and Republican incumbent). ${ }^{4}$ Here, we can see more clearly how much influence incumbency status has on voting behavior. First, we should note that incumbency engenders the greatest movement when we look at House elections. At its weakest, movement from Democratic incumbent to Republican incumbent increases the probability of voting for the Republican candidate by 39 .

The picture is a bit muddier for the Senate and gubernatorial elections. In 1990, it appears that incumbency status produces a greater change in voting behavior for gubernatorial elections than Senate elections. In fact, gubernatorial elections look much like House elections. When, however, we turn to the other two election years, we can see that Senate and gubernatorial elections look more like each other than either look like House elections with regard to the power of incumbency status.

Looking at the open seat row of each portion of Table 2, we can see what happens without the power of incumbency on vote choice. Of course, we should note that this reflects the self-selection out of running, at least for House and Senate candidates for whom no term limits apply. We can get a sense of the general trends in the dispositions of the voters. In 1990, there was still a preference for the Democrats. In 1994, there was a decided movement toward the Republican Party. Last, in 1998, there appears to have been some movement back to the Democratic Party. We should also note that in 
Table 1. Vote Choice by Incumbency: Gubernatorial, House, and Senate Races

\begin{tabular}{|c|c|c|c|}
\hline & Gubernatorial & House & Senate \\
\hline \multicolumn{4}{|l|}{1990} \\
\hline Incumbency & $.48 * *$ & $1.32 * *$ & $.69 * *$ \\
\hline Constant & -.20 & -.16 & -.23 \\
\hline $\mathrm{R}^{2}$ & .02 & .21 & .07 \\
\hline $\mathrm{N}$ & 751 & 610 & 440 \\
\hline \multicolumn{4}{|l|}{1994} \\
\hline Incumbency & $.40 * *$ & $.85 * *$ & $.51 * *$ \\
\hline Constant & .10 & .27 & .36 \\
\hline $\mathrm{R}^{2}$ & .02 & .09 & .03 \\
\hline $\mathrm{N}$ & 764 & 869 & 764 \\
\hline \multicolumn{4}{|l|}{1998} \\
\hline Incumbency & $.76^{* *}$ & $.84 * *$ & $.54 * *$ \\
\hline Constant & -.31 & -.28 & -.20 \\
\hline $\mathrm{R}^{2}$ & .04 & .10 & .05 \\
\hline $\mathrm{N}$ & 517 & 461 & 415 \\
\hline \multicolumn{4}{|c|}{$\begin{array}{l}\text { Note: Vote Choice scored } 0=\text { Democrat and } 1=\text { Republican. Incumbency scored }-1=\text { Democratic } \\
\text { incumbent, } 0=\text { Open Seat, and } 1=\text { Republican incumbent. } \mathrm{R}^{2} \text { is the McFadden pseudo } \mathrm{R}^{2} \text { provided } \\
\text { by Stata. } \\
\text { *Significant at } .05 \text { level, two-tailed; ** significant at } .01 \text { level, two-tailed. }\end{array}$} \\
\hline
\end{tabular}

Table 2. Probability of Voting Republican by Incumbency Status

\begin{tabular}{lccc}
\hline & Gubernatorial & House & Senate \\
\hline $\mathbf{1 9 9 0}$ & .25 & & \\
Democrat Incumbent & .42 & .24 & .33 \\
Open Seat & .61 & .43 & .45 \\
Republican Incumbent & .36 & .64 & .59 \\
Rep. Inc. - Dem. Inc. & & .40 & .26 \\
1994 & .42 & & \\
Democrat Incumbent & .52 & .36 & .46 \\
Open Seat & .62 & .57 & .59 \\
Republican Incumbent & .20 & .75 & .70 \\
Rep. Inc. - Dem. Inc. & & .39 & .24 \\
1998 & .33 & & .28 \\
Democrat Incumbent & .45 & .19 & .44 \\
Open Seat & .57 & .46 & .61 \\
Republican Incumbent & .24 & .57 & .33 \\
Rep. Inc. - Dem. Inc. & & & \\
\hline
\end{tabular}




\section{2 | Brad Lockerbie}

open seat races in off-year races, the two parties are rather evenly matched in 1998. Even in the other two years, the advantage of the dominant party is not overwhelming. Regardless of the level of election or the year, never is the probability of voting for the dominant party in an open seat race greater than .59. In four of the nine cases, the probability of voting for the dominant party is at or below .55. The issue of translating votes into seats aside, it looks as though neither party is overwhelmingly dominant.

While seeing that in the bivariate case that incumbency matters and also that incumbency matters most for House elections is not surprising, we need to look at more than the bivariate case. There are, of course, other variables that we need to look at aside from incumbency status. Many works (Abramowitz 1985; Fiorina 1981b; Kinder and Kiewiet 1979 and 1981; Kramer 1971 and 1983; Kuklinski and West 1981; Lewis-Beck 1988a and 1988b; Lockerbie 1991; etc.) on voting behavior suggest a strong economic component. The equations to follow include two economic items. First, there is a retrospective item measuring how the respondents evaluate the performance of the national government with regard to their personal finances. This item is available for 1990 and 1994. In 1998, the equations make use of the item asking the respondents to evaluate the performance of the national government with regard to the most important problem facing the nation. ${ }^{5}$ Following Kramer (1971), I assume that in the case of divided government, the party of the president is held accountable for the state of the economy. Most voters when they think of the national government think of the most visible individual - the president. ${ }^{6}$ Second, there is an item that asks the respondents which party will do a better job of managing the national economy.

There are at least two potential problems with making use of these items. First, do citizens assign responsibility to the national government for changes in their personal financial situation? Kramer (1983) argues quite persuasively that only those changes in the economy for which voters hold the government responsible should influence voting behavior. The items in the equations to follow explicitly incorporate that sense of attribution. Each question specifically calls for the respondent to evaluate the government's performance. In 1990, 28 percent of those asked about the government's affect on their financial situation gave a non-neutral response. Similarly, in 1994, 33 percent gave a non-neutral response to this same question. Unfortunately, this question was not employed in the 1998 survey. Instead, the respondents were asked to evaluate the government's management of the most important problem facing the nation. Not surprisingly, given the different focus of the question, a much greater percentage (58 percent) gave a non-neutral response. The prospective item asks the respondents to evaluate the parties' relative abilities to provide a prosperous future. ${ }^{7}$ Here, 
instead of the government being referenced, the capacities of the political parties are being referenced. One might argue that the economic items are being given their best chance to show an influence on voting behavior. Given that the retrospective item changes in 1998 (going from egocentric to sociotropic) and the prospective item is consistently sociotropic, we should be careful when making judgments about either the time orientation or the egocentric/sociotropic orientation of the electorate.

A second problem is that none of the ANES contain a similar set of items with regard to the responsibility of the state government. While many scholars (Chubb 1988; Kenney 1983; Kingston 1989; Turett 1971) have found little, or no effect, of state economic variables on gubernatorial outcomes, one should also note that others (Atkeson 1995; Carsey 1998; Kone and Winters 1993; and Niemi et al. 1995) have found a modest effect for state economic policy changes on gubernatorial votes. While Atkeson (1995) and Carsey (1998) have found little effect of national economics on these state contests, Holbrook-Provo (1987), Chubb (1988), Kingston (1989), and Niemi et al. (1995) have, found that national economic conditions influence electoral decisions in gubernatorial contests. Although we will not be able to ascertain whether evaluations of state economics are consequential for these elections, we will be able to get a sense of the role of evaluations of the national government's abilities on one's vote choice across a range of elections. Stein (1990) argues that there should not be much national economic voting because it is unlikely that citizens take the national economy into account when voting in gubernatorial races. Stein, however, does discuss the possibility that there might be across the board responsibility. Votes might be cast in state based races on the basis of the national economy because voters are employing an across the board party responsibility model. ${ }^{8}$

Why should we expect national economics to play a role in these elections? First, the easiest, House and Senate elections are about who will serve in the national legislature. Aside from the presidency, these two elective offices are the ones where it would make most sense for these items to have an influence. While neither Senators nor members of the House are able by themselves to dictate national policy, they are part of the government that makes national policy. Second, the more difficult, governors are not part of the government that makes the national policy. Why would voters take these national considerations into account when casting a ballot in a purely state level race? While gubernatorial elections are not national in scope, the candidates on the ballots are attached to a national party label. Voters may be using this as a cue. If one is pleased (displeased) with the performance of the national party, one might well be inclined to support (oppose) its candidates regardless of whether it is a state or national level office. Certainly, the national media discusses gubernatorial elections as a statement about the 
relative standing of the two political parties. When looking at the prospective economic items, a similar logic applies. If one thinks a party will provide for a prosperous or poor future, one might be inclined to think that fellow partisans below the national level will perform similarly at the state level. Consequently, one's gubernatorial vote might be influenced by evaluations of the national government and the two parties.

Aside from the economic items, the models also have non-economic performance items. Specifically, in each of the years the respondents are asked to evaluate the relative position of the United States in the world. In two of the three years, the respondents are asked to evaluate which party, if either, would be better at managing foreign affairs. The logic that applies above with the economic items applies here as well. Governors, for example, have little, if anything, to do with the position of the United States in the world. ${ }^{9}$ Voters, nonetheless, might hold gubernatorial candidates responsible for the performance and the expected performance of their respective parties. Moreover, these items are included so that each of the equations within a year will have an identical specification. Consequently, any findings for a particular year that appear cannot simply be explained away as the result of differing specifications of the equations.

There are two additional variables in each of the equations. Aside from looking at incumbency and performance, voters might have a concern about the policies that governments adopt. How the goal is achieved might be important, aside from the achievement of the goal itself. Of course, we are all aware that a large segment of the voting public does not have a well-defined sense of ideology. Nonetheless, a large percentage of survey respondents, especially when we look at the subset of voters, respond to the question of ideology. Specifically, the survey asks the respondents to place themselves on a seven point scale of ideology ranging from extremely liberal to extremely conservative. Perhaps, when asked this general question, voters can give a reasoned response that they are unable to offer when asked about specific issues. ${ }^{10}$ Regardless of the exact meaning of this item, it should prove to be a reasonable control variable. Last, I include party identification. It is commonly held that only after party identification is taken into account, can we hope to assess the influence of other variables on vote choice. Niemi, Stanley, and Vogel $(1995,944)$, for example, state that "a model of individual voting would hardly be complete without party identification." Only if some variable has an influence on voting behavior after controlling for party identification will we accept that it does influence vote choice. ${ }^{11}$ Campbell et al. (1960) long ago demonstrated the efficacy of party identification on voting behavior. An examination of The New American Voter (1996) shows this approach continues today. Here, I include the simple three point scale of party identification. Moreover, party identification should 
serve as a useful reference point to judge the relative efficacy of the other items in the equations. ${ }^{12}$

Table 3 shows the multivariate logistic regression equations of vote choice for each of the years under investigation. The first number in each equation is the unstandardized coefficient. The second number is the standardized coefficient. ${ }^{13}$ First, let us examine the most obvious. Even in the face of several reasonable control variables, we can see that incumbency is a statistically significant influence on voting behavior across each of these types of elections and across each of these years. How does incumbency status compare to the standby of models of voting behavior-party identification? Here, we can observe some differences across the various types of elections. With regard to the gubernatorial elections, we can see that party

Table 3. Multivariate Equations of Vote Choice in Gubernatorial, Senatorial, and House Elections

\begin{tabular}{lccc}
\hline & Gubernatorial & House & Senate \\
\hline 1990 & & & \\
Incumbency & $.53 / .17^{* *}$ & $1.47 / .46^{* *}$ & $.96 / .36^{* * *}$ \\
Recon & $-.28 /-.08$ & $.17 / .04^{* *}$ & $.29 / .08$ \\
Pgov & $.63 / .18^{* *}$ & $1.06 / .25^{* *}$ & $.34 / .09$ \\
Rpos & $.01 / .00$ & $-.16 /-.04$ & $-.02 /-.01$ \\
Pfa & $.47 / .14^{*}$ & $.38 / .09$ & $.86 / .23^{* *}$ \\
L/C & $.17 / .10^{*}$ & $.30 / .14^{* *}$ & $.34 / .18^{* *}$ \\
PID & $1.04 / .36^{* *}$ & $.91 / .26^{* *}$ & $.90 / .29^{* *}$ \\
Constant & -3.20 & -5.24 & -5.55 \\
$\mathrm{R}^{2}$ & .29 & .45 & .33 \\
Null percent & 53.08 & 59.16 & 55.32 \\
Model percent & 76.63 & 81.46 & 79.33 \\
PRE & .50 & .55 & .54 \\
$\mathrm{~N}$ & 552 & 453 & 329
\end{tabular}

Note: Incumbency and vote choice are scored as before. Recon is scored $1=$ Federal economic policy has hurt one to $5=$ Federal economic policy has helped one. Pgov is scored $1=$ Democratic Party would provide for a more prosperous future to $3=$ Republican Party would provide for a more prosperous future. Rpos is scored $1=$ the position of the United States in the world has gotten weaker to 3 = the position of the United States in the world has gotten stronger. Pfa is scored $1=$ Democratic Party better able to handle foreign affairs to $3=$ Republican Party better able to handle foreign affairs. $\mathrm{L} / \mathrm{C}$ is scored $0=$ extremely liberal to $6=$ extremely conservative. PID is scored $0=$ Democrat, $1=$ Independent, and $2=$ Republican.

The first number in each column is the unstandardized coefficient. The second number is the standardized coefficient. The null percent is the percentage of time one would be correct guessing the modal vote. The model percent is the percentage of time one is correct by using the model. PRE is the proportionate reduction in error statistic.

*Significant at .05, two-tailed; **significant at .01, two-tailed.

(table continues) 
Table 3 (continued)

\begin{tabular}{|c|c|c|c|}
\hline & Gubernatorial & House & Senate \\
\hline \multicolumn{4}{|l|}{1994} \\
\hline Incumbency & $.54 / .20 * *$ & $1.16 / .37 * *$ & $.69 / .21 * *$ \\
\hline Recon & $-.28 /-.08$ & $-.13 /-.04$ & $-.33 /-.09 *$ \\
\hline Pgov & $.70 / .19^{* *}$ & $.61 / .15^{* *}$ & $.96 / .25 * *$ \\
\hline Rpos & $-.34 /-.10 *$ & $-.20 /-.05$ & $-.20 /-.05$ \\
\hline $\mathrm{L} / \mathrm{C}$ & $.35 / .19 * *$ & $.44 / .21 * *$ & $.54 / .27 * *$ \\
\hline PID & $1.09 / .35 * *$ & $1.22 / .36 * *$ & $.85 / .26^{* *}$ \\
\hline Constant & -2.17 & -2.86 & -3.08 \\
\hline $\mathrm{R}^{2}$ & .36 & .41 & .40 \\
\hline Null percent & 54.78 & 54.51 & 57.49 \\
\hline Model percent & 80.40 & 81.28 & 81.19 \\
\hline PRE & .57 & .59 & .56 \\
\hline $\mathrm{N}$ & 648 & 732 & 654 \\
\hline \multicolumn{4}{|c|}{ Note: All is scored as described above. } \\
\hline & Gubernatorial & House & Senate \\
\hline \multicolumn{4}{|l|}{1998} \\
\hline Incumbency & $.93 / .24 * *$ & $1.26 / .40 * *$ & $.81 / .38 * *$ \\
\hline Recon/Rprob & $-.37 /-.09$ & $-.06 /-.01$ & $-.31 /-.08$ \\
\hline Pgov & $.26 / .08$ & $.37 / .10$ & $.19 / .06$ \\
\hline Rpos & $-.26 /-.07$ & $-.02 /-.01$ & $-.43 /-.12$ \\
\hline Pfa & $.32 / .09$ & $.35 / .09$ & $.90 / .24 * *$ \\
\hline $\mathrm{L} / \mathrm{C}$ & $.38 / .20 * *$ & $.54 / .25^{* *}$ & $.27 / .13 *$ \\
\hline PID & $1.22 / .38^{* *}$ & $1.18 / .33 * *$ & $1.19 / .35^{* *}$ \\
\hline Constant & -2.87 & -4.51 & -2.99 \\
\hline $\mathrm{R}^{2}$ & .39 & .43 & .43 \\
\hline Null percent & 51.26 & 50.69 & 53.19 \\
\hline Model percent & 81.16 & 81.27 & 84.19 \\
\hline PRE & .61 & .62 & .66 \\
\hline $\mathrm{N}$ & 398 & 363 & 329 \\
\hline
\end{tabular}

identification is always more important than incumbency status. Looking at House elections, we see just the opposite. While incumbency is more powerful than party identification in each of the three years, we should note that in the last two elections in the table the difference in the power of the two variables is not terribly large; in 1994 it is but .01. Looking at Senate 
elections, we can see that incumbency is also most powerful vis-à-vis party identification in 1990. In the later two years studied, we can see that incumbency status and party identification are much closer in power. For both of these legislative elections, the power of incumbency on individual vote choice appears to have become somewhat weaker.

How important is incumbency across these three types of elections? We can examine the influence of incumbency status on vote choice by examining the probability of voting for a candidate change by incumbency status once we have taken account of all these other factors that are shown in Table 3. Table 4 shows the probabilities of voting Republican by incumbency status once everything else in the equations is set at the mean level. There is one feature that is clear regardless of how quickly one skims the table; incumbency status is clearly most important for explaining vote choice in House elections. Gubernatorial and Senate vote choice, where the elections both have statewide constituencies, is less affected by incumbency status. Nonetheless, the picture still shows, however modestly, that incumbency status is more important for Senate vote choice than for gubernatorial vote choice. ${ }^{14}$

Looking at these elections over these three election years does not show much change in the power of incumbency. There is, however, at least one finding worth noting. The change in probability of voting for a Republican by incumbency status is lower for both House and Senate elections in 1994

Table 4. Probability of Voting Republican by Incumbency Status with Everything Else at Mean

\begin{tabular}{lccc}
\hline & Gubernatorial & House & Senate \\
\hline 1990 & .34 & .15 & .21 \\
Democrat Incumbent & .47 & .43 & .42 \\
Open Seat & .60 & .77 & .65 \\
Republican Incumbent & .26 & .62 & .44 \\
Rep. Inc. - Dem. Inc. & & & \\
1994 & .43 & .36 & .50 \\
Democrat Incumbent & .56 & .64 & .66 \\
Open Seat & .69 & .85 & .79 \\
Republican Incumbent & .26 & .49 & .29 \\
Rep. Inc. - Dem. Inc. & & & \\
1998 & .23 & .17 & .28 \\
Democrat Incumbent & .43 & .43 & .47 \\
Open Seat & .65 & .72 & .66 \\
Republican Incumbent & .42 & .55 & .38 \\
Rep. Inc. - Dem. Inc. & & & \\
\hline
\end{tabular}


than in either 1990 or 1998 . With all that occurred in 1994, incumbency does not seem to have been as powerful in 1994 as it had been before or after. Looking at the constants tells us that the slant to the electorate was different in 1994 than it was in 1990. Each of the constants is higher in 1994 than in 1990, thereby indicating that the electorate was less inclined toward the Democratic Party's candidates in 1994 than in 1990. Looking in 1998, we see movement back in the direction of the Democratic Party in gubernatorial and House elections. Senate elections do not look appreciably different in 1998.

The consistency of the incumbency items is not matched by the performance items. Looking at the retrospective economic items, one sees that there are occasions in which they are statistically significant, but one can hardly make an argument that they dominate these equations. Even when they are statistically significant, they do not come close to the power of either incumbency or party identification. The prospective items fare little better than their retrospective counterparts. With the exception of the Senate elections of 1990, they are significant in every vote choice model for 1990 and 1994. When we look at 1998, the prospective items fall short of statistical significance, regardless of which office we examine. Moreover, they are only close in the House vote choice equation (.09 level, two-tailed). In the gubernatorial and Senate equations for 1998, the prospective economic item does not come close at all (.21 and .42 , two-tailed, respectively). ${ }^{15}$

Looking for consistency across the equations and types of elections with regard to the prospective economic evaluations is a daunting task. In the gubernatorial elections of 1990 and 1994, the prospective economic item is approximately one-half the power of party identification. In House elections, we see that in 1990 the prospective economic item has approximately the same power as party identification, but by 1994 it has dropped in relative power. Comparing the prospective economic item to incumbency in these two elections shows that in gubernatorial elections the items are relatively equal in power regardless of which of the two elections one examines. Similarly, one can see that the prospective economic item is substantially weaker than the incumbency item in House elections for both years. This would seem to indicate that House members are better able to insulate themselves from the fortunes of their national party than are incumbent governors.

If we turn to the non-economic performance items, we see that they are largely inconsequential. It is intriguing to note, however, there is one consistent finding here. In no case are the foreign affairs items significant in gubernatorial elections. Perhaps voters are distinguishing between the types of offices and the responsibilities of the officers. Governors do not make foreign policy, so why should it be relevant for voters in gubernatorial contests. This does undercut the argument that voters are simply using these 
evaluations as a summary measure of the parties' competency. These items, when they are significant, are significant in legislative elections. While individual legislators are not responsible for the state of the nation in the realm of foreign policy, they do have the opportunity to play a role in its formation and execution.

Looking at the items that were put in largely as controls, we can see the expectations are met. Not surprisingly, party identification is strongly related to vote choice regardless of year and level of office. ${ }^{16}$ Regardless of the year or office examined, it is one of the two most powerful variables in the equation. Moreover, it appears that party identification became a stronger influence on voting behavior across the 1990s. Ideology is, across the board, an important influence on vote choice. This would seem to indicate that voters are concerned with items aside from performance. Aside from the success or failure of a policy, voters appear to be concerned with how policies are made and implemented.

\section{Discussion}

At the end of a manuscript scholars like to write about all their consistent findings, how everything comes out as expected. Occasionally, however, this wish is not fulfilled. ${ }^{17}$ When we look at the economic evaluations, we see little consistency. In some years the economic evaluations are important for some offices. There is, however, no readily recognized pattern to the significance of the coefficients for the economic items, except to note that the prospective evaluations are significant more often than the retrospective items. A look at the non-economic performance items shows that the functional responsibility argument to be relevant. In 1990 and 1998, the only two years for which the item is available, the prospective foreign affairs item is significant in Senate elections and not House elections. However, we should note the prospective foreign affairs item is significant in the gubernatorial voting equation for 1990, but not 1998. So again, not everything matches up as nicely as we might hope.

The power of incumbency played out just as one might expect. Incumbency is most relevant for House voting. Looking at Senate and gubernatorial elections does not show us a clear picture. There seems to be little distinction between them with regard to the power of incumbency. Perhaps because of the broader constituencies of senators and governors, they are less electorally safe than are members of the House. Senators, despite being one of 100, are no more able than governors to take advantage of incumbency. 


\section{NOTES}

${ }^{1}$ Looking at other years in the 1990 s is desirable. Unfortunately, one is plagued with especially small samples for gubernatorial elections in presidential election years.

${ }^{2}$ This, of course, assumes that the candidate is not running for office for the first time after having been appointed to office.

${ }^{3}$ See Jacobson (2001) for an elaboration on these points. Specifically, he is making the case for differentiating House from Senate campaigns. The logic, however, should, for the most part, carry over to gubernatorial campaigns as well.

${ }^{4}$ Using Gary King's Clarify software (see King, Tomz, and Wittenberg 2000), we can see that the confidence intervals around each of the probabilities do not overlap.

${ }^{5} \mathrm{~A}$ listing of all the variables and their coding can be found in the notes attached to the tables.

${ }^{6}$ If this argument is not accurate, we should note that the retrospective economic items are strongest for 1994 - the only year of the study with unified government.

${ }^{7} \mathrm{An}$ anonymous reviewer suggested that the retrospective and prospective items might be highly correlated. Once we measured one, the other would be redundant. The correlation between the two economic items is .03, -.26, and .12 in 1990, 1994, and 1998 respectively. Consequently, the evidence supports the idea that the retrospective and prospective items are theoretically and empirically distinct.

${ }^{8} \mathrm{His}$ discussion on page 42 states that the voting goes across levels. Voters hold the president's party responsible and vote accordingly across the board. A test of the Hibbing/Alford argument that voters only reward or punish incumbents of the president's party is not supported here. Interaction terms for this (incumbent of the president's party and the retrospective items) fail to gain significance.

${ }^{9}$ The functional responsibility argument clearly is not in play here. Some might have a concern that voters are not paying attention to foreign affairs when voting. Until recently, that has been the prevailing view in political science. Aldrich, Sullivan, and Borgida (1989), however, find that voters are paying attention to foreign affairs and voting on them when the candidates show substantial differences. Also, note that Fiorina (1981b) found that voters are paying some attention to foreign affairs when voting.

${ }^{10}$ See Conover and Feldman (1984) for a discussion of the symbolic meaning of the responses to the ideology item.

${ }^{11}$ While Fiorina's (1978) earlier manuscript does include party identification as an independent variable explaining vote choice, his book (1981) is one of the rare exceptions of a model of vote choice that specifically does not include party identification.

${ }^{12} \mathrm{An}$ anonymous reviewer noted that ideology and party identification might be getting at the same thing. Accordingly, I checked the correlation between the two items and found that it was never larger than .45. Moreover, the when checking for multicollinearity, I found that the highest VIF was 2.06 - well below the point at which we would assert that there was a consequential problem (Kennedy 2003).

${ }^{13}$ See Long (1997) for a discussion of the standardization of logit coefficients. If one ignores the dichotomous nature of the dependent variable and runs OLS, the results, including the standardized coefficients, look much the same as that presented here.

${ }^{14}$ Using Gary King's Clarify software (see King, Tomz, and Wittenberg 2000), we can see that the probabilities of voting for the Republican are significantly different for House elections across the values for incumbency status. In Senate elections, the differences are significant in 1990 and 1994, and nearly so in 1998. Gubernatorial elections, in contrast, always have some overlap. 


\footnotetext{
${ }^{15}$ One might think that multicollinearity is a likely culprit. An examination of the VIFs shows them all to be below 3.00, thereby indicating that multicollinearity is not the cause of the lack of statistical significance.

${ }^{16}$ Of course, if Fiorina (1981) is correct in his assessment of party identification as a running tally of one's evaluations of the political parties, the power of the performance items is understated in these analyses.

${ }^{17}$ Or perhaps, when the findings do not line up nicely, the manuscript languishes in a file drawer.
}

\section{REFERENCES}

Abramowitz, Alan I. 1985. Economic Conditions, Presidential Popularity, and Voting Behavior in Midterm Congressional Elections. Journal of Politics 47:31-43.

Abramowitz, Alan I. 1988. Explaining Senate Election Outcomes. American Political Science Review 82:385-403.

Achen, Christopher H. 1989. Prospective Voting and the Theory of Party Identification. Presented at the annual meeting of the American Political Science Association.

Aldrich, John H., and Forrest D. Nelson. 1986. Logit and Probit Models for Multivariate Analysis with Qualitative Dependent Variables. In New Tools for Social Scientists, eds. William D. Berry and Michael S. Lewis-Beck. Beverly Hills: Sage Publications.

Aldrich, John H., John L. Sullivan, and Eugene Borgida. 1989. Foreign Affairs and Issue Voting: Do Presidential Candidates Waltz Before a Blind Audience. American Political Science Review 83:123-141.

Arnold, R. Douglas. 1979. Congress and the Bureaucracy: A Theory of Influence. New Haven, CT: Yale University Press.

Bibby, John F. 1983. Patterns in Midterm Gubernatorial and State Legislative Elections. Public Opinion, February/March, p. 41-46.

Burnham, Walter Dean. 1974. Communications. American Political Science Review 68:210.

Cain, Bruce, John Ferejohn, and Morris Fiorina. 1987. The Personal Vote: Constituency Service and Electoral Independence. Cambridge, MA: Harvard University Press.

Campbell, Angus, Phillip E. Converse, Warren E. Miller, and Donald R. Stokes. 1960. The American Voter. New York: Wiley.

Campbell, James E., and Joe A. Sumners. 1990. Presidential Coattails in Senate Elections. American Political Science Review 84:513-524.

Chubb, John E. 1988. Institutions, the Economy, and the Dynamics of State Elections. American Political Science Review 82:133-154.

Cowart, Andrew T. 1973. Electoral Choice in the American States: Incumbency Effects, Partisan Forces, and Divergent Partisan Majorities. American Political Science Review 67:835-853.

Erikson, Robert S. 1972. Malapportionment, Gerrymandering, and Party Fortunes in Congressional Elections. American Political Science Review 66:1234-1245.

Erikson, Robert S., and Gerald C. Wright. 1989. Voters, Candidates, and Issues in Congressional Elections. In Congress Reconsidered, eds. Lawrence C. Dodd and Bruce I. Oppenheimer. Washington, DC: Congressional Quarterly Press.

Feldman, Stanley. 1982. Economic Self-Interest and Political Behavior. American Journal of Political Science 26:446-466. 


\section{2 | Brad Lockerbie}

Feldman, Stanley. 1985. Economic Self-Interest and the Vote: Evidence and Meaning. In Electoral Conditions and Electoral Outcomes: The United States and Western Europe, eds. Heinz Eulau and Michael S. Lewis-Beck. New York: Agathon Press.

Fenno, Richard F., Jr. 1972. If as Ralph Nader Says, Congress is 'the Broken Branch,' How Come We Love our Congressmen So Much? In Congress in Change, ed. Norman J. Orienstein. New York: Praeger.

Ferejohn, John A. 1977. On the Decline of Competition in Congressional Elections. American Political Science Review 71:166-176.

Fiorina, Morris P. 1977. Congress: Keystone of the Washington Establishment. New Haven, CT: Yale University Press.

Fiorina, Morris P. 1981a. Some Problems in Studying the Effects of Resource Allocation in Congressional Elections. American Journal of Political Science 25:543-567.

Fiorina, Morris P. 1981b. Retrospective Voting in American National Elections. New Haven: Yale University Press.

Holbrook-Provo, Thomas M. 1987. National Factors in Gubernatorial Elections. American Politics Quarterly 15:471-483.

Jacobson, Gary C. 2001. The Politics of Congressional Elections, 5th ed. Boston: Longman.

Jewell, Malcolm. 1982. The Neglected World of State Politics. Journal of Politics 44: 638-657.

Jewell, Malcolm, and David Olson. 1988. Political Parties and Elections in the American States, 3d ed. Chicago: Dorsey Press.

Johannes, John R., and John C. McAdams. 1981. The Congressional Incumbency Effect: Is it Casework, Policy Compatibility, or Something Else? An Examination of the 1978 Election. American Journal of Political Science 25:512-542.

Jones, Charles O. 1981. New Directions in U.S. Congressional Research. Legislative Studies Quarterly 6:455-468.

Kennedy, Peter. 2003. A Guide to Econometrics. Cambridge, MA: MIT Press.

Kenney, Patrick J. 1983. The Effect of State Economic Conditions on the Vote for Governor. Social Science Quarterly 64:154-162.

Kessel, John H. 1988. Presidential Campaign Politics: Coalition Strategies and Citizen Response. Chicago: Dorsey Press.

Kinder, Donald R., and D. Roderick Kiewiet. 1979. Economic Discontent and Political Behavior: The Role of Personal Grievances and Collective Economic Judgments in Congressional Voting. American Journal of Political Science 23:495-527.

Kinder, Donald R., and D. Roderick Kiewiet. 1979. Sociotropic Politics: The American Case. British Journal of Political Science 11:129-161.

King, Gary, Michael Tomz, and Jason Wittenberg. 2000. Making the Most of Statistical Analyses: Improving Interpretation and Presentation. American Journal of Political Science 44:347-361.

Kingston, M. Jean. 1989. Explaining Gubernatorial Election Outcomes, 1950-1985. Ph.D. diss., University of Georgia, Athens.

Kramer, Gerald H. 1971. Short-Term Fluctuations in U.S. Voting Behavior, 1896-1964. American Political Science Review 65:131-143.

Kramer, Gerald H. 1983. The Ecological Fallacy Revisited: Aggregate versus Individuallevel Findings on Economics and Elections. American Political Science Review 77:92-111.

Kuklinski, James, and Darrell West. 1981. Economic Expectations and Voting Behavior in the United States Senate and House Elections. American Political Science Review 75:436-447. 
Lewis-Beck, Michael S. 1980. Applied Regression: An Introduction. Beverly Hills: Sage Publications.

Lewis-Beck, Michael S. 1988a. Economics and the American Voter: Past, Present, Future. Political Behavior 10:5-21.

Lewis-Beck, Michael S. 1988b. Economics and Elections: The Major Western Democracies. Ann Arbor: University of Michigan Press.

Lockerbie, Brad. 1989. Change in Party Identification: The Role of Prospective Economic Evaluations. American Politics Quarterly 17:291-311.

Lockerbie, Brad. 1991. Prospective Voting in U.S. House Elections, 1956-1988. Legislative Studies Quarterly 16:239-261.

Lockerbie, Brad. 1999. The Partisan Component to the Incumbency Advantage: 19561996. Political Research Quarterly 52:631-646.

Long, J. Scott. 1997. Regression Models for Categorical and Limited Dependent Variables. Thousand Oaks, CA: Sage Publications.

MacKuen, Michael B., Robert S. Erikson, and James E. Stimson. 1989. Macropartisanship. American Political Science Review 83:1125-1142.

Mayhew, David R. 1974. Congress: The Electoral Connection. New Haven, CT: Yale University Press.

Ornstein, Norman J., Thomas E. Mann, and Michael Malbin. 1987. Vital Statistics on Congress, 1987-1988. Washington, DC: Congressional Quarterly Press.

Patterson, Samuel C. 1982. Campaign Spending in Contests for Governor. Western Political Quarterly 35:457-477.

Pierson, James E. 1977. Sources of Success in Gubernatorial Elections, 1910-1970. Journal of Politics 39:939-958.

Seroka, James. 1980. Incumbency and Reelection: Governors versus U.S. Senators. State Government 53:161-165.

Sniderman, Paul, and Richard Brody. 1977. Coping: The Ethic of Self-Reliance. American Journal of Political Science 21:501-522.

Squire, Peverill. 1992. Challenger Profile and Gubernatorial Elections. Western Political Quarterly 45:125-142.

Stein, Robert M. 1990. Economic Voting for Governor and U.S. Senator: The Electoral Consequences of Federalism. Journal of Politics 52:29-53.

Tompkins, Mark E. 1984. The Electoral Fortunes of Gubernatorial Incumbents: 19471981. Journal of Politics 46:520-543.

Tompkins, Mark E. 1988. Have Gubernatorial Elections Become More Distinctive Contests? Journal of Politics 50:192-205.

Tufte, Edward R. 1973. The Relationship Between Seats and Votes in Two-Party Systems. American Political Science Review 67:540-554.

Turret, J. Stephen. 1971. The Vulnerability of American Governors, 1900-1969. Midwest Journal of Political Science 15:108-132.

Yiannakis, Diana Evans. 1981. The Grateful Electorate: Casework and Congressional Elections. American Journal of Political Science 25:568-580. 
